\title{
Effects of Periodic Applications of Simazine on the Production of Tilapia nilotica Fingerlings ${ }^{1}$
}

\author{
Andrew S. McGinty \\ ABSTRACT
}

The yield of Tilapia nilotica fingerlings after 126 days was $52 \%$ less in fiberglass pools $\left(4.12 \mathrm{~m}^{2}\right)$ treated periodically with $1 \mathrm{mg} / \mathrm{l}$ simazine than in untreated control pools. About $30 \%$ of this reduction seemed to be in response to the low abundance of natural foods (phytoplankton) in treated pools.

\section{INTRODUCTION}

Small experimental tanks and pools often develop dense phytoplankton blooms if water is not changed frequently. In some studies it is necessary to observe fish without disturbing them. Simazine is an algicide that has been used for aquatic macrophyte and phytoplankton control in fish ponds (3). This study was designed to determine the effects of periodic applications of simazine on the growth of Tilapia nilotica fingerlings in pools.

\section{MATERIALS AND METHODS}

This study was conducted at the Lajas Agriculture Research and Development Center of the University of Puerto Rico in eight circular fiberglass pools $\left(4.12 \mathrm{~m}^{2}\right)$ with an average depth of $45 \mathrm{~cm}$. Each pool was stocked with 100 Tilapia nilotica swim-up fry (less than $12 \mathrm{~mm}$ in total length) which had been previously passed through a $3 \mathrm{~mm}$ mesh grader. Four pools were treated with $1 \mathrm{mg} / \mathrm{l}$ simazine (2-chloro-4,6bis(ethylamino)-s-triazine) $0,24,56,87$, and 106 days after fish were stocked. The other four pools were not treated and served as controls. All fish were fed twice a day, 5 days per week, a finely ground, $32 \%$ protein ration at an equal percent total body weight. The initial feeding rate was $10 \%$ but was gradually decreased to $2 \%$ by the end of the study. The maximum amount fed was $10 \mathrm{~g} / \mathrm{m}^{2} /$ day. Pools were not cleaned and only water lost by evaporation was replaced.

No fewer than 57 fish were weighed every 3 weeks. After 126 days all the fish in each pool were counted and weighed, and the experiment terminated. On the basis of previous weighings of individual fish, a sample of 57 out of 100 fish should provide an estimate within $3.5 \%$ of the true weight $(\mathrm{P}=0.05)$. Since sampling error was small, each sample date could be evaluated for treatment effects. A $t$ test was used to

${ }^{1}$ Manuscript submitted to Editorial Board November 21, 1983.

${ }^{2}$ Department of Marine Sciences, University of Puerto Rico, Mayagüez, P.R. 00708 USA. 
determine differences in average weights and survival of fish between treatments.

\section{RESULTS AND DISCUSSION}

Survival was $91 \%($ S.E. $=2.1)$ in control pools and $87 \%($ S.E. $=1.2)$ in treated pools, and were not significantly different $(\mathrm{P}>0.05)$. After only 42 days the average weight per 100 fish was significantly less $(\mathrm{P}<$ 0.05 ) for the treated pools. This difference became more apparent throughout the remainder of the study (table 1 ). The average yield of tilapia was $52 \%$ greater in control pools after 126 days. A $20 \%$ reduction in yield of channel catfish (Ictalurus punctatus) in ponds treated with simazine was reported by Tucker and Boyd (4), Tucker and Boyd (5), and Tucker et al. (6). The greater reduction in yield of tilapia in comparison to that of channel catfish is likely a result of tilapia's ability to feed upon phytoplankton (1). Lovell (2) reported a contribution of only $2.5 \%$ by natural productivity to channel catfish reared in ponds,

TABLE 1.-The average weight (g) per 100 Tilapia nilotica reared in control pools and pools treated with $1 \mathrm{p} / \mathrm{m}$ simazine $0,24,56,87$, and 106 days after fish were stocked. Each value represents the average weight \pm the standard error for four pools

\begin{tabular}{|c|c|c|c|c|c|}
\hline \multicolumn{6}{|c|}{ Days after stocking } \\
\hline 21 & 42 & 63 & 84 & 105 & 126 \\
\hline $79 \pm 6$ & $269 \pm 9$ & $563 \pm 13$ & $\begin{array}{l}\text { Treated } \\
1,052 \pm 32 \\
\text { Control }\end{array}$ & $1,630 \pm 77$ & $1,879 \pm 122$ \\
\hline $92 \pm 7$ & $388 \pm 23$ & $839 \pm 43$ & $1,422 \pm 48$ & $2,112 \pm 54$ & $2,705 \pm 72$ \\
\hline
\end{tabular}

whereas J. M. Kubaryk ${ }^{3}$ found a contribution of about $30 \%$ by natural productivity for $T$. nilotica reared in ponds.

Tucker et al. (6) suggested a possible direct effect of the simazine on growth of channel catfish since reduced growth was observed even after water quality was comparable to that of their control ponds. It is likely that a combination of effects resulted in the reduced yield observed with catfish and tilapia. Given a $20 \%$ reduction in yield due to a combination of the direct effect of simazine and poorer water quality, a $32 \%$ reduction resulted from the decreased natural productivity of the diet of tilapia in treated pools. This estimate is very close to Kubaryk's. ${ }^{3}$

The coefficient of variation (CV) for average weight was considerably less for treated pools until the 84th day, when CV was about equal between treatments. After this, CV remained relatively constant for control pools at $5-6 \%$, whereas CV for treated pools increased to $13 \%$ by harvest. Initial differences are probably a result of variability in the establishment of algal populations in control pools. Once a certain density

\footnotetext{
${ }^{3}$ Personal communication.
} 
of phytoplankton became established, the contribution of natural foods stabilized and CV subsequently declined. The response was reversed in treated pools where supplemental foods were the primary food source. Nutrient inputs from supplemental foods were equal, resulting in lower CV initially for treated pools in the absence of variable phytoplankton densities. However, as nutrient inputs and wastes increased, water quality declined and CV increased. Tucker et al. (6) found considerable pond to pond variation in the effect of simazine on water quality, and were unable to determine the magnitude or duration of the effect.

Simazine was effective in decreasing algal blooms and increasing water clarity in small pools. However, simazine decreased the yield of $T$. nilotica; thus its use could not be recommended for static systems managed for maximum production. Simazine could be useful for experimental trials to decrease variability between experimental units provided that water quality not be allowed to decline drastically. It might also be useful when direct observations of fish are required, ie., for behavior studies, detection of fry in spawning units, etc. However, the direct effect of simazine would have to be determined in advance.

\section{RESUMEN}

Cien alevines recién nacidos de Tilapia nilotica se echaron en varios estanques de Fiberglas (fibra de vidrio) de $4.12 \mathrm{~m}^{2}$. Cuatro de los estanques se trataron periódicamente con 1 ppm de simazine, mientras que los restantes sirvieron de control; esto es, no se les aplicó tratamiento alguno. Los resultados demonstraron que el rendimiento en la producción de peces juveniles en los estanques tratados fue un 52\% menor que en los no tratados. Aparentemente, el $30 \%$ de esta reducción fue causada por la escasez de alimento natural, tal como fitoplancton en los estanques que no se trataron.

\section{LITERATURE CITED}

1. Bowen, S. H., 1982. Feeding, digestion and growth-qualitative considerations, p. 14156. In R. S. V. Pullin and Lowe-McConnell (Ed). The Conference Proceedings 7, 432 p. International Center for Living Aquatic Resources Management, Manila, Philippines.

2. Lovell, T., 1977. Estimate needed on contribution of pond organisms to fish feed, Comm. Fish Farmer and Aquacult. News 3 (5): 30.

3. Mauck, W. L., 1974. A review of the literature on the use of simazine in fisheries, U.S. Fish Wild. Serv. Rep. FWS-LR-74-16.

4. Tucker, C. S. and C. E. Boyd, 1978a. Consequences of periodic applications of copper sulfate and simazine for phytoplankton control in catfish ponds, Trans. Am. Fish. Soc. 107: 316-20.

5. _ a and — 1978b. Effects of simazine treatment on channel catfish and bluegill production in ponds, Aquaculture 15: 345-52.

6. — _ R. L. Bush and S. W. Lloyd, 1983. Effects of simazine treatment on channel catfish production and water quality in ponds, J. Aquat. Plant Manag. 21: 7-11. 